\title{
Personal encounters with children in an informal settlement: Exploring spirituality
}

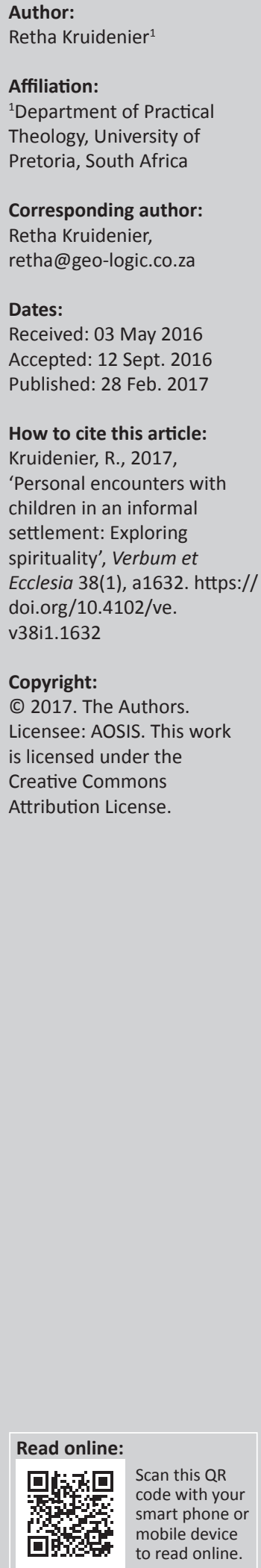

This article explores the factors that contribute to the children living in Zama Zama informal settlement's spiritual development. Postfoundational practical theology and the narrative approach function as paradigm and methodology. Themes and/or discourses like power, poverty, nutrition, health and school enrolment were identified. The faith development theory is discussed, as well as a reflection on children's spirituality. The research shows that the faith community, crèche and other partners play a crucial role in the spiritual development of the children.

Intradisciplinary and/or interdisciplinary implications: This study was performed in the field of practical theology. The article is interdisciplinary, covering the fields of religion, psychology, social work, sociology and health studies.

\section{Introduction}

This article tells a story of a journey and is a reflexive account of my experiences and personal encounters with children in an informal settlement in Pretoria West, called Zama Zama. Zama Zama is one of many informal settlements, also known as 'squatter camps', around the City of Tshwane. The research participants of the study were selected infants and children that lived in Zama Zama. The principal of the Zama Zama School of Hope, as well as the parents of the children played an important part in the retelling of the children's stories to me.

People who live in these informal settlements do so in difficult and poor circumstances. This research project hopes to give voice to the experiences of the children who lived in Zama Zama at the time when the research was done and explores the factors that contributed to the spiritual development or not, of the children. It also explores the role played by students from the University of Pretoria and the influence of pastoral care provided by volunteers and non-governmental organisations (NGOs) to the children of Zama Zama School of Hope in their spiritual development.

\section{Narrative enquiry}

The research was done by using narrative research methodology. According to the narrative metaphor, we experience our lives through stories. We give meaning to our lives and relationships through stories. These stories emanate from people's cultures, families and experiences. 'Narrative research is thus the study of how human beings experience the world, and narrative researchers collect these stories and write narratives of experience' (Moen 2006:56).

Thinking with stories is thinking relationally as a narrative inquirer. We need to think with stories in multiple ways: toward our stories; toward other's stories; toward all the social, institutional, cultural, familial and linguistic narratives in which we are embedded as well as toward what begins to emerge in the sharing of our lived and told stories. Narrative texts can grasp the living moments of the subject's subtle interrelatedness with the world (Clandinin et al. 2011:34; Hateley 2016; Tamboukou 2010). Narrative inquiry is grounded in relationships that offer both researcher and participants a narrative space for telling and retelling experiences they have lived and are living. As stories are retold, possibilities emerge for reliving these stories in more thoughtful and responsive ways in the future.

The narrative researcher deconstructs the sometimes abusiveness of research projects and do not pathologise or victimise their narrators. In narrative research, the interviewees become the 'coresearchers'. The research does not serve the researcher's objectives alone, but must be of value for those being researched. We invite the respondents to tell their stories in their own way and speak in their own voices (Müller, Van Deventer \& Human 2002:81). 
The narrative researcher strives to conduct research as a form of practical wisdom, which values the stories of people and communities, instead of working with hypotheses of what should or might be. The contribution of the researcher is to reflect and facilitate and wait until the plot emerges. To allow the stories of people and communities to be fully told, the researcher that works from a narrative perspective is in a 'not-knowing position'. The 'not-knowing position' allows the researcher to ask questions to research participants which are not informed by method and scientific answers (Human 2003:42; Swart 2013:2).

\section{Postfoundational practical theology}

For this research project, I positioned myself as a postfoundationalist practical theologian. Practical theology is an in-between discipline between various theological disciplines. It is also multilingual in the sense that it speaks the language of the humanities, social sciences and theology at the same time. Müller (2015) describes it as a 'dangerous location'. In this in-between land, the practical theologian is confronted with and exposed to multiple realities and a variety of narratives. Here the voices of the marginalised and powerless people can be heard and new stories can be imagined. In this in-between land, the practical theologian will also become vulnerable and fragile. The practical theologian can never be in a neutral space. Our own stories become part of the research story. Because Africa is the continent where the research takes place, my practical theology is influenced by ideas of liberation theology, black women's theology and feminist theology.

In doing this type of research, focus must be on a specific and concrete 'moment of praxis' that is always local, embodied and situated. Practical theological knowledge is local knowledge, dealing with specific persons in their particular contexts. It cannot function in general contexts and the methodology must start with a specific context or praxis to theory and back again to the context (Dreyer 2014; Müller 2005:78).

Postfoundational practical theology is an effort to move beyond the modernistic boundaries of practical theology. It is also an effort to avoid the relativism of anti-foundational theories. Its initial perspectives are highly contextual and its performances transcend the local and the concrete and ultimately facilitate interdisciplinarity. It is a third way, a way out of being stuck in modernistic or foundationalist science and theology on the one hand, and the fatalism of some postmodernistic approaches on the other hand (Müller 2004:297; Van Huyssteen 2006:22).

\section{A theology of embodiment}

Doing research about and with children asks for an exploration of body theology. Body theology is tangent with postfoundational practical theology. My body became an instrument in doing the research and building trustworthy relationships. I carried the infants, hugged the children and played with them. As they got used to me and started to trust me, relationships were built. A baby of 11 months old was at first cautious when I picked her up and did not show any emotion. After a while, she started to smile when she saw me and held out her little arms to be picked up.

Body theology is a feminist liberation theology that deliberately engages with questions of the body and holistic approaches to 'enfleshed' thinking about humans and about God. Body theologians reject dualistic thinking that would have us place the spirit above the body and deny the body; instead, they focus on the unity of body, mind and spirit (Isherwood 2004:140). Sex, sexuality, sexual abuse and any other physical, sensory experiences cannot be seen as separate events that can be removed from spirituality.

\section{According to Fowler (1987), (Tisdale 1990):}

We are our bodies. With embodiment comes a set of more or less integrated systems and functions that, largely without any conscious effort on our parts, constitute the remarkable concatenation of energy and animation that we call life or living. Embodiment brings with it certain ground rhythms. It brings a range of energy levels, an ease or difficulty of coordination, a bone structure and musculature with their indications of physical strength and endurance, a facial mask with its particular range of expressive features. With embodiment, there also comes another of the primary elements of selfhood: sexuality, erotic energies and needs, and the bases of gender identity. (p. 56)

According to Sheppard (2003:7) we as practical theologians:

need to pay attention to the various sites where 'the body' is directing our attention. We need to have the experience of the body speaking meaning to us, and [we need] to contribute to the many voices that are laying claim to the right and responsibility of making meaning of experiences of embodiment. We need to consider 'the body' in the context of a society where certain bodies are exploited to create a desire for commodities regardless of the need or the ability to afford them, where the color of our skin continues to so greatly influence our quality of life, our experiences in society and our economic location, where poor women and children coexist alongside great abundance. (Sheppard 2011:n.p.)

Miller-McLemore (2013:744) asks the question how the physical (sensual, somatic, visceral, material, carnal, mortal, fleshy, vulnerable) dimensions of our bodies inform our thoughts and knowing. How do actual physical bodies shape religious and theological knowledge? For her, embodiment theology gives meaning to the way practical theologians work on the ground (Doehring 2015).

A theology of presence and touch is part of embodiment theology. Fertman (2013:98) describes a theology of touch as tangible, earthy and physical. It is in the everyday tasks, like getting up, bathing, grooming, eating, going to work or going to look for work. For him, kindness is love in action like doing little things for people. There is a relationship between theology and touch. Acts of kindness can only be accomplished by touching people. 


\section{A playful approach}

Because most children prefer to interact in a playful way, I used a playful and imaginative approach in my research with the children (Friedrich 2008). Serious discussions and methodological problem-solving may inhibit children's communication, shutting out their voices and inhibiting their special abilities, knowledge and creative resources. When children and adults meet, play provides a common language to express the breadth and depth of thoughts, emotions and experience (Caine \& Steeves 2009:1; Müller 2015).

Engaging with each other in a narrative and playful way can make it possible to create an equal and balanced landscape between the researcher and research participants (bibliotherapy.pe.kr). Play also tends to create a lighter atmosphere wherein children are invited to be inventive in dealing with their problems, instead of being so immobilised by blame, guilt or shame (Freeman, Epston \& Lobovits 1997:xv). The 'play' with each other in laughter and suffering makes it possible to place the researcher and the research participant's imaginings in the present time and space (Kearney 1988:218; Müller 2015).

\section{Power as discourse}

When doing research with children, the position of the researcher is crucial. The researcher must be mindful of the differences in power between themselves and the children they are meeting. In research with children, the invitation for adults to reproduce dominant cultural practices of marginalisation is ever-present. This is true for all children by nature of their age and size, and is particularly true for some children when experiences of gender, class, race and cultural background are considered (White \& Morgan 2006:59).

I was aware and sensitive to the fact that I was a white middle class woman trying to do research with vulnerable, impoverished children in an informal settlement. These factors automatically put me in a power position. During the time of the research, I visited the Zama Zama School of Hope often. When I arrived at the nursery school and the children saw me, they would start shouting 'Umlungu, Umlungu'! The principal of the crèche told me that it meant 'white person'. The term 'white person' is already political loaded, because it refers to white people being rich and privileged.

Eze (2010:96) gives an explanation to the history of the word 'Umlungu': Generally, the term 'ubuntu' originates from Nguni languages. The noun-stem of the Nguni term encapsulates the essence or quality of being human. This 'essence' or 'quality' is autochthonous to the practices of what makes one human in these societies. It is for this reason that persons outside the linguistic-geopolitical unit in these societies are not necessarily accorded the same degree of essence or quality. People who are non-blacks, especially white people, are not 'precisely fully human', as evident in the language game of these societies. In these Nguni languages, a white person is 'Umlungu', which means 'white people', with a benign emphasis on difference. In Tsonga, it means that a white person has no relatives, money is his or her relative. The term gives the impression that the quality of being human is exclusively for blacks, excluding persons of other races.

As our relationship became stronger, the principal of the crèche taught them to call me and other white people visiting them 'teacher', instead of 'Umlungu'. This act reflected the growth and sensitivity that were present between the local people and strangers in Zama Zama.

\section{The stories of children living in Zama Zama}

Doing research in an informal settlement with young children and their parents was challenging. As researcher, I was challenged to work creatively with what was available, because resources were reduced to the bare minimum. Kapuściński (1998) has travelled throughout Africa many times. His encounters with children in Africa confirmed my experiences. According to him, half the population of Africa is less than 15 years of age. Hunger for these children is something permanent, a way of life, second nature. And yet they do not ask for bread or fruit, or even money. 'They ask for a pencil'.

Many children in Africa grow up in difficult circumstances because of the combination of factors governing their socio-economic, cultural and developmental circumstances. It is recognised that for optimal development, a child requires particular care with regard to physical and mental health, moral and social development, and the experience of happiness, love and understanding. Developmental endpoints are dependent upon interactions between the environment at the household and community levels, and the child (Fotso, Holding \& Ezeh 2009:175).

Children living in squatter camps are vulnerable on many levels, as in the case of the children that lived in Zama Zama during the time of my research. Pseudonyms are used to protect the children's identities. From my encounters with the children, interviews with their parents, as well as conversations with the principal of the creche, the following discourses were a reality for children of Zama Zama.

\section{Poverty}

Zama Zama is an informal settlement in Pretoria West, which is a poverty-stricken area. Poverty affects white people, as well as black people living in the area. Zama Zama is one of four informal settlements in the area. Most of the people living in Zama Zama are migrants from African countries. At first, the squatter camp was located up the hill, but a few years ago, all the people were moved downhill, opposite SA Bricks on Hornsnek Road in Pretoria West. The community favoured this new location, as the stands were larger (Kruidenier 2015). 
In Zama Zama, the dwellings that the people lived in were shacks made of corrugated iron, and in most cases, consisted of only one room. They lived in these 'houses' with their children and often shared it with other families to keep costs as low as possible. They lived in very poor conditions with only the basic amenities to try to make a living. These individuals were responsible for the household activities, queued to get some water and look after their children. Most of them were single mothers or their partners and husbands worked in other cities or on the mines. Some of the men had jobs at SA Bricks, opposite Zama Zama (Kruidenier 2015).

The women and their children were also often the victims of violence, sexual abuse, drug and alcohol abuse, domestic violence and robbery, which were all part of their daily lives. As an example, a few years ago, a 4-year-old girl was raped. Most of the people were either unemployed or work once or twice a week. This showed the grim reality of these children's lives and demonstrated the poverty-ridden plight of so many women and their children (Kruidenier 2015).

These research findings are confirmed by research done by Stats SA (2014):

The number of people in South Africa living below the bread line increased to 15.8 million in 2009 from 12.6 million in 2006, before dropping to 10.2 million people in 2011. The proportion of the population lived below the upper-bound poverty line has decreased substantially from 2006 to 2011. In 2006, more than half $(57.2 \%)$ of the population of South Africa were living in poverty. The levels of poverty among males and females have seen similar reductions from 2006 to 2011. The experience of poverty was more intense for females, as shown by the poverty gap - this measure was $28.2 \%$ in 2006 as compared with $25.2 \%$ for males. There were significant differences in poverty levels between the population groups in South Africa; in terms of poverty distribution, more than 9 out of $10(94.2 \%)$ poor people in South Africa were black Africans in 2011. (n.p.)

According to Stats SA (2014) it is very clear that the highest levels of poverty were among the younger sections of the population. In 2006, more than two-thirds $(68.9 \%)$ of all children (those aged 17 and younger) in the country were living in poverty. The relationship between education and poverty appeared strong - as the poverty measures reflected, the lower the level of education attained, the more likely adults were to be poor and experienced more intense levels of poverty.

\section{Nutrition and health}

Many of the children in Zama Zama did not eat enough during the day and got to bed hungry, because of the lack of food at home.

The Medical Faculty of the University of Pretoria's dietetic and medical students have started an evaluation of the nutritional status of children at Zama Zama. Of the 42 children that had been evaluated, 10 had malnutrition (mild to moderate) and 6 or 7 children needed more serious intervention. Forty percent of the children at Zama Zama suffered from malnutrition (University of Pretoria Medical Students' Report 2015).
Malnutrition is a serious medical condition marked by a lack of energy and a deficiency in essential proteins, fats, vitamins and minerals in a diet. Over 10 million children aged less than 5 years die annually from preventable and treatable illnesses - almost all these deaths occur in poor countries. Malnutrition contributes to more than one-third of all deaths of children under five. Currently, 195 million children under five are affected by malnutrition; $90 \%$ of them live in subSaharan Africa and South Asia. Malnutrition is the most recognisable and perhaps most untoward consequence of poverty in children. Children aged 6-59 months are considered to be particularly susceptible to acute nutritional stress (Olack et al. 2011:357).

Intervention had already been started in Zama Zama. The children who suffered from malnutrition were receiving balanced food parcels from the Dietetics Department of the University of Pretoria. The NGOs and churches that were involved in Zama Zama supported the community and especially the crèche with balanced food on a weekly basis. Parents were educated in preparing balanced meals for their families.

\section{School enrolment}

A few of the children went to school, because there was no transport available to nearby schools. In addition, children were often left alone for days as the mothers went in search for jobs.

Precious and Beauty's story:

Precious and Beauty were 9 year old twin sisters who lived in Zama Zama, with their mother, older brother and younger sister. Their mother was expecting a new baby. They were from Mozambique and came to live in Zama Zama 4 years ago. The twin's mother had no job and had no man to support her. All of her children had different fathers. Sometimes she bought fish and then sold the grilled fish to the community in Zama Zama. She was Shangaan speaking and couldn't understand English. This made it difficult to communicate with her. The twins were in the nearby school 2 years ago. The previous year she got the news that the school couldn't accommodate the twins any longer. This caused stress for her, because she wanted them to have an education. She did not have money for transport for the twins to go to other schools. They attend the crèche by then, and she was so grateful for the principal who accommodated them and kept them busy. The principal's comment was: 'They are such clever kids and so eager to learn. They want to be in a primary school where they can learn with other 9 year olds'.

\section{The lack of emotional support and the provision of love and care}

Children in Zama Zama lacked emotional support and loving care. Some of the parents had to work long hours, and when they came home at night there was no time to give emotional support to their children. Children as young as 4 years old were expected to look after their siblings; their younger 
siblings therefore became their responsibility. In some cases, children were left alone in the streets.

Temba's story:

Temba was 7 years old and mentally disabled. His parents worked during the day and at first left him alone all day by himself. He wandered in the streets, but when the other children saw him they ran away, because of his disability. They were scared of him and in return, when they came near him, he started beating them. The principal of the crèche had compassion on him and let him join the crèche. She was patient with him and kept on hugging and loving him. After a while his behaviour changed and he hugged back and started to play with the other children. The principal also taught the other children to love him, although he was different from them.

\section{Faith development}

During the time I spent in Zama Zama, I became curious about the faith development of the children and I explored the factors that could possibly contribute to the children's faith development. A brief overview on faith development is therefore necessary.

Faith seems to have a broadly recognisable pattern of development. This unfolding pattern can be characterised in terms of developing emotional, cognitive, and moral interpretations and responses. Our ways of imagining and committing in faith correlate with our ways of knowing and valuing more generally. Faith may be characterised as an integral, centreing process, underlying the formation of the beliefs, values and meanings that give coherence and direction to persons' lives. Faith development must be looked at in a lifespan perspective. It involves an ongoing process of forming and reforming our ways of being and seeing the world (Fowler 1986:37; Fowler \& Dell 2006:34).

Jean Piaget developed a model of general intellectual development (Fowler 2003:238; Watts, Nye \& Savage 2002:85). Piaget's studies of children's thinking on a variety of matters map the psychological landmarks that distinguish the intellectual style of the infant, the pre-schooler and the school-age child, until the emergence of a recognisably adult style in adolescence. Piaget's pioneering theory of infancy, preoperational, concrete operational and formal operational stages contributed to the framing of the faith development theory (Fowler 2001).

Erikson categorises the lifespan in terms of the social conditions people typically face at different stages of their lives. He has woven together attention to biological development, ego development and correlated socio-cultural supporting matrices for development (Fowler 2003:238, 2001; Watts et al. 2002:106). This stresses the fact that religious development is more often stimulated by features of our personal context, rather than the entreaties of a church-led agenda. He observes important changes in our social context at various stages of the life cycle. As infants, we are vulnerable and dependant on other people. After that, we pass through periods of tentative self-control and independence in childhood.
Erikson's main message concerns the sequence of emotional conflicts that are primed at each social period. Our development depends on how these conflicts are resolved positively or negatively. Positive resolution strengthens the personality for the ongoing journey through life, since the outcome furnishes the personality with a new virtue at each stage (Fowler 2003:238; Watts et al. 2002:107).

James Fowler claims that faith 'develops' in the sense that aspects of faith changes over time. He makes the claim that six stages of faith may be discerned, revealing a sequence of stages through which people move. A faith stage is a 'structural whole' in which there is a measure of equilibrium between the processes of the different aspects of faith. This method attempts to focus on the underlying structures and operations of human thought and belief. It tries to understand and define the laws or patterns the mind employs in constructing the ideas, concepts and beliefs that constitute the contents of thinking and valuing.

\section{According to Fowler and Dell (2006):}

Faith taken in this broad sense is a common feature of human beings. Faith begins with basic trust, as the child forms bonds with the mother and other intimate caregivers. As the child matures physically and emotionally, faith accommodates the development of an expanding range of object relations. Exposure to religious symbols and practices may nurture a sense of relatedness to the transcendent. (p. 34)

Fowler identifies six stages of faith (Watts, Nye \& Savage 2002:110); primal faith, intuitive-projective faith, mythicliteral faith, synthetic-conventional faith, individuativereflective faith, conjunctive faith and universalising faith. When looking at the stages of faith, the complex interplay of factors that must be taken into account are biological maturation, emotional and cognitive development, psychosocial experience, the role of religio-cultural symbols, meanings and practices. This complexity is increased when considering gender and race.

Fowler's faith development theory has come under some criticism and much of it has to do with Fowler's understanding of faith (Dykstra 1986:46). An alternative to Fowler's theory is given by Cobb (1975:87). Sometimes, it means a vision of reality or a structure of existence. It can also refer specifically to the Christian vision of reality of the Christian structure of existence. Faith in a different sense is the substance of things hoped for. It is defined as a relation to another and sometimes as a property of the individual. A pluralistic approach should be open to accepting them all and sorting out their complex interconnections with one another and their varying relations with Christ and with other religious traditions.

Postmodern scholars have also criticised Fowler's theory for the lack of specific and nuanced attention to difference, as in attending to minority person's actual experiences (Fowler 2003:236, 2001). Postmodernists have made important contributions to deconstructing the (apparently) universalising forms of conceptions of the self. Postmodernists join feminist 
theorists in viewing these concepts as artefacts of white, male Western culture.

\section{A reflection on children and spirituality}

For me, 'spiritual development' was a more suitable and inclusive term, rather than 'faith development' for exploring spirituality with the children of Zama Zama as research participants. The term 'spirituality' is used in so many different ways by so many different people, traditions, disciplines and cultures. Few people see very little difference between religion and spirituality, but most make a clear distinction. Religion tends to be associated with what is publicly available, such as churches, mosques, Bibles, prayer books, religious officials, weddings and funerals. It also includes uncomfortable associations with boredom, narrowmindedness and being out of date. It seems that in many people's minds, religion is firmly caught up in the cold brutalities of history. Spirituality is almost always seen as much warmer, associated with love, inspiration, wholeness, depth, mystery and personal devotions like prayer and meditation (Hay \& Nye 1998:6; Mueller 2010).

Spirituality is the intrinsic human capacity for selftranscendence in which the individual participates in the sacred - something greater than the self. It propels the search for connectedness, meaning, purpose and ethical responsibility. It is experienced, formed, shaped and expressed through a wide range of religious narratives, beliefs and practices, and is shaped by many influences in family, community, society, culture and nature (Yust et al. 2006:8).

Research shows that children organise reality from early on in terms of ontological categories, distinguishing physical from mental, animate from inanimate and natural from supernatural kinds of things. Children are prepared to think about natural and supernatural possibilities (Crompton 1999:82). This view about children differs radically from the traditional Piagetian view in which young children are characterised as fundamentally confused about kinds and causes of things in the world. These rich, intuitive capacities of children are culturally nurtured and recruited (Johnson \& Boyatzis 2006:211).

Spiritual development arises from the same human cognitive capacities that led to the emergence of art, science and technology. Spiritual development is an integral part of normal, human cognitive developmental mechanisms and processes. These cognitive capacities depend on culture, just as culture depends on these capacities (Van der Ven 2008).

The cognitive-cultural foundation for spiritual development is normally established within the first few years of life. Children distinguish ordinary actions from special, magical powers of wishing or prayer. They come to appreciate that there is a deeper reality behind appearance. Young children are also coming to understand and participate in practices of play, prayer and narrative that serve to orient and connect them to higher possibilities. Spiritual concerns are propelled by intrinsic links between cognition, emotion and value (Johnson \& Boyatzis 2006:213).

Children's spiritual experiences were clustered into four core qualities of spiritual experience, defined as sensing a changed quality in awareness, value, mystery, meaningfulness or insight (Nye 1996:2-8). Children express experience that can be described as spiritual in many ways and at any age. It can be expressed through a capacity for silence and reflection, concentration and delight in play, happiness in his or her own company. Children are born with spiritual competence, an inner quality or power for faith development. Spirituality, spirit or soul is literally embodied within the human body.

\section{African views on spiritual development}

Because my research participants were Africans, African views on children and spirituality have to be explored. There are differences between the African and Western views on spiritual development. Children are the embodiment of the creative power of life in African societies. They are a gift that resembles the very presence of God in the community. In this part of the world, infants are often considered the most spiritual of all humans (Gottlieb 2006:151). They symbolise in the most powerful way the budding of life and the guarantee of fruitfulness, which includes the promise of a new future for the community. Among indigenous communities in Africa, children are regarded as an investment of hope in the whole society, because the community not only survives, but also thrives through children. No individuals or parents can claim exclusive 'ownership' of a child. Children belong to the human community as well as to the ancestors and to God, the giver of life.

The cosmos is a sacred place in which relationships between human beings and the world of nature symbolise the manifestation of the kindred spirits. Children mediate this spiritual reality because they come from the very vortex of life. The vitality of life is present in all human beings and is brought to fruition during the birth of a child. The ancestral world of kindred spirits is connected to the temporal world through procreation as well as through the embodiment of memory in the naming of a child. The birth of a child ensures that there is no discontinuity in the great chain of being that connects both the temporal world and the ancestral world with the kindred spirit. This spirit is cultivated as a child grows from infancy into adulthood (Otieno 2006:122).

African traditions embrace the innocence of spiritual childhood as a moral paradigm of life. Every aspect of human experience is valued and connected to the whole continuum of things on the basis of ritual and celebration. A child is perceived as a gift from the spiritual world of ancestors to the human community. 


\section{The importance of the faith community in the spiritual development of children}

The language, rituals and teachings of particular communities of faith are of critical importance for faith and spiritual development. Although the child's faith always depends upon his or her own construction of images and insights, religious language, rituals and ethical teachings do awaken the child to the domain of faith; they channel his or her attention toward the transcendent (Fowler 1987:39).

The faith community and local church in Zama Zama played an important role in the spiritual and faith development of the children. The female pastor of the church was also the principal of the crèche. She built into their daily routine rituals of prayer and worship and told them stories from the Bible. They took part in prayer before they had their meals. These children learned through experience. Children also took part in the friendship and worship of the faith community; they experienced what was happening long before they could understand or do their own faith practices. Christian values like love, respect and honesty were being taught to them. The faith community gave the children a place to learn to serve and to love others. They experienced simple acts of sharing and not always getting their own way by sharing the food after each church service.

When I did research with these children, the nuclear family of 'mom, dad and two kids living in suburbia' was not the norm. 'It takes a family to raise a child' described families in informal settlements better. 'Family' in this context is any bonded network of domestic life and nurture (Groome 2003:207). Because the mothers had to work long hours, or searched for days for work, the children became the responsibility of the community, and in many children's cases, the responsibility of the crèche. The crèche became their home.

Groome (2003:208) mentions four functions of the family as partners in the spiritual development of children: family as witness, which means that the whole life of the home should be suffused with the values and perspectives of Christian faith. The family in the second place must be a worshipping community which integrates shared prayer and sacred ritual into its patterns of daily life. Every family needs its own liturgy to symbolise and celebrate its faith. The family must be in the third place an agent of welfare, which requires care for spiritual, physical and emotional well-being of its own members, rippling outward to responsibility for others and society. Family life must reflect love and compassion toward all, promoting justice within itself and the social values of God's reign in the world. In the last place, family as community of Word calls it to share its faith around scripture and tradition, within itself and the broader community.

The different role players that worked together in Zama Zama contributed to the spiritual development of the children and provided structures for the nurturing of the children. All the programmes contributed to the building of relationships with the children and the bigger community. When children are welcomed into full participation in the faith community and when they are known and loved by many in the community, they have a sense of belonging and identity (Stonehouse 2006:105). This was indeed the case in Zama Zama.

The music therapist's music programme was aimed at the empowerment of the children, the creation of a supportive atmosphere and their interaction in social activities. Theological students played with the children, touched them and held Bible schools weekly. Because many of the children had no father figure in their lives, the love and attention of these young men were of crucial importance to the spiritual awakening of the children and their understanding of God. A group of volunteers visited the community once a week and did occupational therapeutic intervention with the children. Holiday programmes by NGOs and churches also contributed in a positive way.

\section{Conclusion}

This article reflected on personal encounters with children living in Zama Zama. It also explored the factors that contributed to the spiritual development of children. Interaction and conversations with the children, their parents and the principal of the local crèche showed that they lived in difficult circumstances characterised by poverty, malnutrition and the lack of education. It is also found that the faith community, crèche and other partners played a crucial role in the children's spiritual development.

\section{Acknowledgements Competing interests}

The author declares that she has no financial or personal relationships which may have inappropriately influenced her in writing this article.

\section{References}

Caine, V. \& Steeves, P., 2009, 'Imagining and playfulness in narrative inquiry', International Journal of Education and the Arts 10(25), 1-11.

Clandinin, D.J., Huber, J., Steeves, P. \& Li, Y., 2011, 'Becoming a narrative inquirer: Learning to attend within the three-dimensional narrative inquiry space', in $S$. Trahar (ed.), Learning and teaching narrative inquiry: Travelling in the borderlands, pp. 33-51, John Benjamins, Amsterdam.

Cobb, J.B., 1975, Christ in a pluralistic age, Westminster Press, Philadelphia, PA.

Crompton, M., 1999, 'Children, spirituality and religion', in P. Milner \& B. Carolin (eds.), Time to listen to children: Personal and professional communication, $\mathrm{pp}$ 79-93, Routledge, London.

Doehring, C., 2015, 'Resilience as the relational ability to spiritually integrate moral stress', Pastoral Psychology 64, 635-649. https://doi.org/10.1007/s11089-015stress',

Dreyer, J.S., 2014, 'The narrative turn in practical theology: A discussion of Julian Müller's narrative approach', Verbum et Ecclesia 35(2), 1-9. https://doi. org/10.4102/ve.v35i2.889

Dykstra, C., 1986, 'What is faith? An experiment in the hypothetical mode', in C. Dykstra \& S. Parks (eds.), Faith development and Fowler, pp. 45-64, Religious Education Press, Birmingham.

Eze, M.O., 2010, Intellectual history in contemporary South Africa, Palgrave MacMillan, Basingstoke, UK.

Fertman, B., 2013, 'The theology of touch', viewed 01 April 2015, from https:// peacefulbodyschool.com 
Fotso, J.C., Holding, P.A. \& Ezeh, A.C., 2009, 'Factors conveying resilience in the context of urban poverty: The case of orphans and vulnerable children in the informal of urban poverty: The case of orphans and vulnerable children in the informal settlements of Nairobi, Kenya', Child and Adolescent Mento
175-182. https://doi.org/10.1111/j.1475-3588.2009.00534.x

Fowler, J.W., 1986, 'Faith and the structure of meaning', in C. Dykstra \& S. Parks (eds.) Faith development and Fowler, pp. 15-42, Religious Education Press, Birmingham.

Fowler, J.W., 1987, Faith development and pastoral care, Fortress Press, Philadelphia PA.

Fowler, J.W., 2001, 'Faith development theory and the postmodern challenges', International Journal for the Psychology of Religion 11, 159-172.

Fowler, J.W., 2003, 'Faith development theory and the challenges of practical theology', in R.R. Osmer \& F.L. Schweitzer (eds.), Developing a public faith: New directions in practical theology-Essays in honor of James W Fowler, pp. 229-250, Chalice Press, St Louis, MO

Fowler, J.W. \& Dell, M.L., 2006, 'Stages of faith from infancy through adolescence: Reflections on three decades of faith development theory', in E.C. Roehlkepartain P.E. King, L. Wagner \& P.L. Benson (eds.), The handbook of spiritual development P.E. King, L. Wagner \& P.L. Benson (eds.), The handbook of spiritual
in childhood and adolescence, pp. 34-44, Sage, Thousand Oaks, CA.

Freeman, J., Epston, D. \& Lobovits, D., 1997, Playful approaches to serious problems: Narrative therapy with children and their families, WW Norton, New York.

Friedrich, J., 2008, 'Children and trauma: A narrative-based playgroup', Journal of Poetry Therapy 21(4), 203-217.

Gottlieb, A., 2006, 'Non-Western approaches to spiritual development among infants and young children: A case study from West Africa', in E.C. Roehlkepartain, P.E. King, L. Wagner \& P.L. Benson (eds.), The handbook of spiritual development in childhood and adolescence, pp. 150-160, Sage, Thousand Oaks, CA.

Groome, T., 2003, 'Children and parents: Two-way partners in faith development', in R.R. Osmer \& F.L. Schweitzer (eds.), Developing a public faith: New directions in practical theology - Essays in honor of James W Fowler, pp. 203-212, Chalice Press, St Louis, Missouri.

Hateley, E., 2016, 'Crossing boundaries with reading: Telling stories about libraries, literacies and learning', New Review of Children's Literature and Librarianship 22(1), 1-14.

Hay, D. \& Nye, R., 1998, The spirit of the child, Harper Collins, London.

Human, L., 2003, 'Fiction writing as a metaphor for research: A narrative approach', Practical Theology in South Africa 18(3), 40-58.

Isherwood, L., 2004, 'The embodiment of feminist liberation theology: The spiralling of incarnation', Feminist Theology 12(2), 140-156. https://doi.org/10.1177/ 096673500401200203

Johnson, C.N. \& Boyatzis, C.J., 2006, 'Cognitive-cultural foundations of spiritual development', in E.C. Roehlkepartain, P.E. King, L. Wagner \& P.L. Benson (eds.), The handbook of spiritual development in childhood and adolescence, pp. 211-223, Sage, Thousand Oaks, CA.

Kapuściński, R., 1998, The shadow of the sun: My African life, transl. K. Glowczewska, Penguin Press, Harmondsworth.

Kearney, R., 1988, The wake of imagination, Routledge, London.

Kruidenier, R., 2015, 'Trying for better circumstances (Zama Zama): Exploring ubuntu amongst marginalised women in an informal settlement', Verbum et Ecclesia 36(2), 1-8. https://doi.org/10.4102/ve.v36i2.1433

Miller-McLemore, B.J., 2013, 'Embodied knowing, embodied theology: What happened to the body?', Pastoral Psychology 62, 743-758. https://doi.org/ 10.1007/s11089-013-0510-3

Moen, T., 2006, 'Reflections on the narrative research approach', International Journal of Qualitative Methods 5(4), 1-11.

Mueller, C.R., 2010, 'Spirituality in children: Understanding and developing interventions', Pediatric Nursing 36(4), 197-203.
Müller, J., 2004, 'HIV/AIDS, narrative practical theology and postfoundationalism: The emergence of a new story', HTS Theological Studies 60(1 \& 2), 293-306. https:// doi.org/10.4102/hts.v60i1/2.516

Müller, J., 2005, 'A postfoundationalist, HIV-positive practical theology', Practical Theology in South Africa 20(2), 72-88.

Müller, J., 2015, 'Exploring "nostalgia" and "imagination" for ubuntu-research: Apostfoundational perspective', Verbum et Ecclesia 36(2), 1-6. https://doi. org/10.4102/ve.v36i2.1432

Müller, J.C., Van Deventer, W. \& Human, L., 2002, 'Fiction writing as metaphor for research: A narrative approach', Practical Theology in South Africa 16(2), 76-96.

Nye, R., 1996, 'Spiritual development', in M. Crompton (ed.), Children, spirituality and religion: A training pack, pp. 6-19, Central Council for Education and Training in Social Work, London.

Olack, B., Burke, H., Cosmas, L., Bamrah, S., Dooling, K., Feikin, D.R. et al., 2011 'Nutritional status of under-five children living in an informal urban settlement in Nairobi, Kenya', Journal of Health Population Nutrition 29(4), 357-363. https:// doi.org/10.3329/jhpn.v29i4.8451

Otieno, N., 2006, 'From naming to initiation: Childhood and adolescence in African Christian spirituality', in K.M. Yust, A.N. Johnson, S.E. Sasso \& E.C. Roehlkepartain (eds.), Nurturing child and adolescent spirituality: Perspectives from the world's religious traditions, pp. 122-131, Rowman \& Littlefield Publishers, Lanham.

Sheppard, P.I., 2003, 'A dark goodness created in the image of God: Womanist notes toward a practical theology of black women's embodiment', The Covenant Quarterly 61(3), 5-28.

Sheppard, P.I., 2011, Self, culture, and others in womanist practical theology, Springe Nature, Palgrave, Macmillan, Basingstoke UK.

Statistics South Africa, 2014, Poverty trends in South Africa: An examination of absolute poverty between 2006 and 2011, Report No. 03-10-06, viewed 01 March 2015, from https://www.statssa.gov.za

Stonehouse, C., 2006, 'After a child's first dance with God: Accompanying children on a protestant spiritual journey', in K.M. Yust, A.N. Johnson, S.E. Sasso \& E.C. Roehlkepartain (eds.), Nurturing child and adolescent spirituality: Perspectives from the world's religious traditions, pp. 95-107, Rowman \& Littlefield Publishers, Lanham.

Swart, C., 2013, Re-authoring the world: The narrative lens and practices for organizations, communities and individuals, Knowres Publishing, Randburg.

Tamboukou, M., 2010, 'Working with stories as multiplicities, opening up the black box of the archive', Life Writing 7(1), 19-33.

Tisdale, J.R., 1990, 'Humanistic psychotherapy assumptions and Christian counselling', Journal of Religion and Health 29(3), 175-191.

Van der Ven, K., 2008, The constructive-use-of-time assets. Promoting positive development in early childhood, Springer, New York.

Van Huyssteen, J.W., 2006, Alone in the world? Human uniqueness in science and theology, Eerdmans, Grand Rapids, MI.

Watts, F., Nye, R. \& Savage, S. 2002, Psychology for Christian ministry, Routledge, London.

White, M. \& Morgan, A., 2006, Narrative therapy with children and their families, Dulwich Centre Publications, Adelaid

Yust, K.M J Johnson, A.N. Sasso, S.E. \& Roehlkepartain, E.C. 2006, 'Traditional wisdom: Creating space for religious reflection on child and adolescent spirituality', in K.M. Yust, A.N. Johnson, S.E. Sasso \& E.C. Roehlkepartain (eds.) Nurturing child and adolescent spirituality: Perspectives from the world's religious traditions, pp. 1-14, Rowman \& Littlefield Publishers, Lanham, MD.

University of Pretoria, 2015, 'Report on nutritional status of children in Zama Zama', Unpublished. 